\title{
Diversity and species composition of arbuscular mycorrhizal fungi in Clerodendrum species
}

\section{Songachan LS*, Kayang $\mathrm{H}$ and Moinao $\mathrm{P}$}

Microbial Ecology Laboratory, Department of Botany, North Eastern Hill University, Shillong-793 022, India.

Songachan LS, Kayang H, Moinao P 2015 - Diversity and species composition of arbuscular mycorrhizal fungi in Clerodendrum species. Mycosphere 6(2), 150-158, Doi 10.5943/mycosphere/6/2/5

\begin{abstract}
Two Clerodendrum species viz., Clerodendrum colebrookianum and Clerodendrum buchananii were studied for diversity of arbuscular mycorrhizal fungi (AMF). A rhizosphere soil was found to be acidic and soil phosphorus was low for both the plant species. AMF colonization in the form of arbuscules, vesicles and hyphae were observed. Hyphal colonization was high compared to vesicles and arbuscules. The percent of AMF colonization in C. colebrookianum was $29.77 \%$, whereas in $C$. buchananii it was $25.83 \%$. However, AMF colonization in trap culture from $C$. buchananii derived inoculum source was found to be higher $(18.07 \%)$ as compared to $C$. colebrookianum $(16.31 \%)$. On the basis of morphological characteristics, a total of 20 AMF species belonging to two genera viz., Acaulospora and Glomus were isolated from the two studied plant species, whereas from trap culture, 14 AMF species were isolated. This study gives the gist of AMF status of two Clerodendrum species and it revealed that the AMF composition and diversity varies in the two Clerodendrum species.
\end{abstract}

Key words - colonization - diversity - mycorrhiza - rhizosphere soils

\section{Introduction}

Arbuscular mycorrhizas are symbiotic relationships between the plant roots and soil fungi belonging to phylum Glomeromycota (Schussler et al. 2001). The ubiquity of arbuscular mycorrhizal fungi (AMF) at the interface between soil and plant roots makes them a key functional group of soil biota. AMF are known to benefit plant establishment by increasing resistance to environmental stresses, enhancing plant nutrient acquisition, water relations, disease resistance and improving soil quality (Smith \& Read 2008).

Clerodendrum species comprised of small trees, shrubs and herbs that belong to the family Verbenaceae (Jadeja et al. 2012). Different species of Clerodendrum are present in different parts of India, although it is mostly confined to the Northeast region, with two commonly found species Clerodendrum colebrookianum Walp. and Clerodendrum buchananii 
Roxb. These species contains saponins, flavonoids, alkaloids, tannins, glycosides and reducing sugars (Adeneye et al. 2008). Traditionally, the crude extracts of the leaves of these plants are used for treatment of high blood pressure, hypertension and for controlling rheumatism by the native people of this region. It was also reported that aqueous leaf extract of $C$. glandulosum Coleb. is traditionally used to alleviate symptoms of diabetes, obesity and hypertension by people of Northeast India (Jadeja et al. 2011). Clerodendrum inerme L. is a medicinal shrub reported to be used in treatment of various ailments (Somasundram \& Sadique 1986, Nakata 1999, Chae et al. 2004). Several classes of secondary metabolites present in the plant extracts are responsible for various biological activities. Thus, Clerodendrum species have been used from time immemorial for its various medicinal properties.

Although several Clerodendrum species has been found to be one of the most well known medicinal plant species having a high demand, AMF association in Clerodendrum species has not been reported so far. One reason which is worrisome is that an increasing demand for plant products may endanger many traditionally used and pharmaceutically important plant species and their habitats (Fuchs \& Haselwandter 2008). Considering the influence of AMF on plants, it is crucial that more attention should be paid to the monitoring of soil and mycorrhizal development during the process of their growth. Moreover, the importance of mycorrhiza for many plant species and the possibilities of its practical application strengthen the need for identification and cultivation of mycorrhizal fungi present in roots of naturally occurring plants (Ryszka et al. 2010). Therefore, the aim of this investigation is to study AMF diversity of $C$. colebrookianum and C. buchananii.

\section{Materials \& Methods}

\section{Study Site and Sampling}

The study was conducted at North Eastern Hill University Campus, Meghalaya, India, located at $25^{\circ} 36^{\prime} 400^{\prime \prime N}, 091^{\circ} 53^{\prime} 57^{\prime \prime} \mathrm{E}$ with an altitude of 1,424 m above sea level. Sampling was done during September to December, 2012. The roots and rhizosphere soils of $C$. colebrookianum and $C$. buchananii (ten replicates of each plant species) were collected in sterilized plastic bags and transported to the laboratory for analysis.

\section{Estimation of AMF colonization}

The root samples were washed thoroughly in tap water, cut it to approximately $1 \mathrm{~cm}$ and cleared in $10 \% \mathrm{KOH}$ for $1 \mathrm{~h}$ at $90{ }^{\circ} \mathrm{C}$, acidified with $1 \% \mathrm{HCL}$ and stained with trypan blue (Philips \& Hayman 1970). The stained root samples were mounted on microscope slides in lactoglycerol and examined for AMF colonization under light microscope. Root lengths with mycorrhizal colonization in the form of arbuscules, vesicles and hyphae in 100 root segments from each plant species were estimated using the magnified intersection method of McGonigle et al (1990).

\section{AMF spore isolation, enumeration and identification}

AMF spores were extracted by wet sieving and decanting method of Uma et al (2010). Suspension of $25 \mathrm{~g}$ rhizosphere soil sample in water was decanted through a series of 710 to 37 $\mu \mathrm{m}$ sieves. The residues on the sieves were washed into beaker with water and filtered through filter papers. Each filter paper was spread on petri dish and spores were counted using a dissection microscope at $40 \times$ magnification. Sporocarps and spore clusters were considered as 
one unit. AMF spores were picked up using a needle, mounted in polyvinyl alcohol-lactoglycerol with Meltzer's reagent. AMF spores were identified based on morphological characteristics such as shape, size, colour, wall ornamentation, etc. using identification keys of International culture collection of vesicular and arbuscular mycorrhizal fungi, i.e. INVAM (http://www.invam.caf.wvu.edu) and AMF phylogeny (www.amf-phylogeny.com). Spore density and species richness were expressed as number of AMF spores and numbers of AMF species in $25 \mathrm{~g}$ soil sample.

\section{Trap culture}

The methods of AMF trap culture were followed from INVAM (http://invam.caf.wvu.edu). Trap cultures were established using Trifolium repens L. as a host plant. Rhizosphere soils and roots of $C$. colebrookianum and $C$. buchananii were collected in a separate plastic bag. Roots were chopped into small fragments and mixed thoroughly with the associated soil that serves as inoculum. This chopped blend is mixed 1:1 (v/v) with autoclaved coarse sand. Seeds of $T$. repens were evenly sown on $25 \mathrm{~cm}$ diameter plastic pots containing the AMF inoculum and monitored in green house for five months. It was watered whenever required. After five months, the roots of the trap plants were evaluated for AMF colonization and spores were isolated and analyzed as described above.

\section{Soil Physico-Chemical Analysis}

Soil $\mathrm{pH}$ was determined using a digital $\mathrm{pH}$ meter. Soil moisture was determined by drying $10 \mathrm{~g}$ fresh soil at $105^{\circ} \mathrm{C}$ for $24 \mathrm{~h}$ in a hot-air oven. Organic carbon was analyzed by colorimetric method (Anderson \& Ingram 1993) and available phosphorus by molybdenum blue method (Allen et al. 1974). The soil physico-chemical properties are presented in Table 1.

Table 1 Soil physico-chemical properties of Clerodendrum rhizosphere soils.

\begin{tabular}{lllll}
\hline Plant species & pH & Moisture Content & Organic Carbon & Phosphorus \\
\hline C. colebrookianum & $6.80 \pm 0.02$ & $7.50 \pm 0.02$ & $1.72 \pm 0.12$ & $0.01 \pm 0.01$ \\
C. buchananii & $7.83 \pm 0.04$ & $7.20 \pm 0.12$ & $1.79 \pm 0.25$ & $0.001 \pm 0.00$ \\
\hline
\end{tabular}

\section{Results}

\section{AMF association}

Arbuscular mycorrhizal colonization were observed in the roots of both $C$. colebrookianum and $C$. buchananii (Table 2). Total AMF colonization was higher in $C$. colebrookianum $(29.77 \%$ ) as compared to C. buchananii $(25.83 \%)$. AMF colonization in trap culture for $C$. buchananii was found to be higher $(18.07 \%$ ) as compared to C. colebrookianum $(16.31 \%)$ as shown in Table 3. The AMF structures found in the two plant species such as hyphae, arbuscules and vesicles are given in Fig. 1.

Table 2 AMF colonization in two Clerodendrum species.

\begin{tabular}{lllll}
\hline \multirow{2}{*}{ Plant species } & \multicolumn{2}{l}{ Mycorrhizal structure } & \multirow{2}{*}{ Total Colonization (\%) } \\
\cline { 2 - 5 } & Arbuscules & Vesicles & Hyphae & \\
\hline C. colebrookianum & $8.32 \pm 0.02$ & $4.23 \pm 0.01$ & $17.23 \pm 0.02$ & 29.77 \\
C. buchananii & $8.75 \pm 0.01$ & $4.21 \pm 0.01$ & $12.87 \pm 0.01$ & 25.83 \\
\hline
\end{tabular}


Table 3 AMF colonization in trap plants (Trifolium repens) with inoculum source from two Clerodendrum species.

\begin{tabular}{lllll}
\hline \multirow{2}{*}{ Plant species } & \multicolumn{2}{l}{ Mycorrhizal structure } & \multirow{2}{*}{ Total Colonization (\%) } \\
\cline { 2 - 4 } & Arbuscules & Vesicles & Hyphae & \\
\hline Trifolium repens (C.c) & $4.23 \pm 0.01$ & $3.13 \pm 0.01$ & $8.95 \pm 0.01$ & 16.31 \\
Trifolium repens (C.b) & $1.96 \pm 0.01$ & $2.61 \pm 0.00$ & $13.50 \pm 0.02$ & 18.07 \\
\hline
\end{tabular}

Note: C.c $=$ Clerodendrum colebrookianum, $\mathrm{C} . \mathrm{b}=$ Clerodendrum bachananii

\section{Statistical analysis}

Relative abundance, isolation frequency, Shannon-Wiener index of diversity $\left(\mathrm{H}^{\prime}\right)$ and Simpson index of dominance were calculated (Dandan \& Zhiwei 2007).
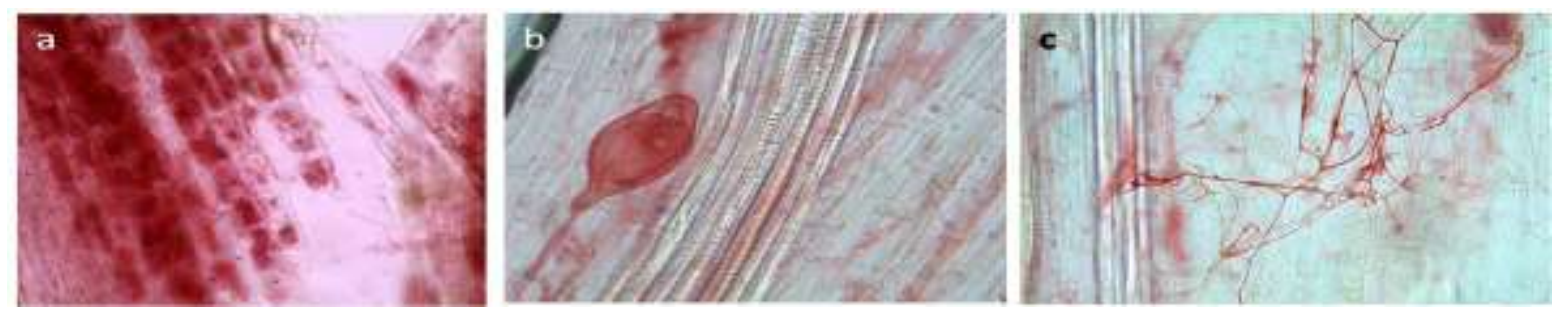

Fig. 1 - Mycorrhizal structural colonization in the roots of Clerodendrum species; (a) Arbuscules (b) vesicles and (c) Hyphae.

\section{AMF composition and diversity}

A total of 20 AMF species belonging to two genera viz., Acaulospora and Glomus (15 AMF species from $C$. colebrookianum and 13 AMF species from $C$. buchananii) were isolated and identified on the basis of morphological characteristics (Table 4). Fourteen AMF species were isolated from the trap cultures belonging to two Acaulospora and Glomus species (Table 5). The AMF spore density in $25 \mathrm{~g}$ dry soil sample each was 643 in C. colebrookianum and 460 in C. buchananii (Fig. 2), whereas in trap culture it was 75 in C. colebrookianum derived trap culture and 58 in C. buchananii derived trap culture (Fig. 3). Micrographs of some of the isolated AMF species from two Clerodendrum species are given in Fig. 4.

Shannon-Weiner index of AMF diversity was found to be 2.29 in C. buchananii and 2.54 in C. colebrookianum, and Simpson's index of AMF was 0.09 in C. colebrookianum and 0.14 in C. buchananii. In the trap culture Shannon's index of AMF C. colebrookianum was found to be 2.00 and Simpson's index was 0.14 and for C. buchananii Shannon's index of AMF was found to be 2.18 and Simpson's index was 2.12.

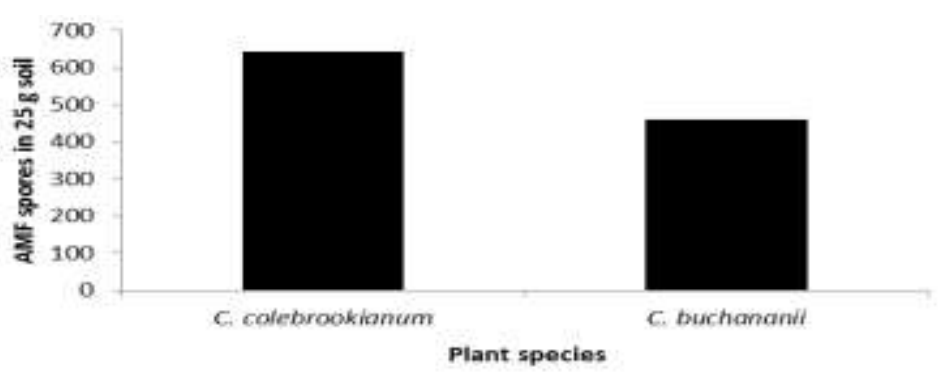

Fig. 2 - AMF spore density in the rhizosphere soil of Clerodendrum species. 
Table 4 AMF species isolated from two Clerodendrum species.

\begin{tabular}{|c|c|c|c|c|}
\hline \multirow{2}{*}{ Sl. No. } & \multirow{2}{*}{ AMF species } & \multicolumn{2}{|c|}{ Relative abundance $(\%)$} & \multirow{2}{*}{ IF $(\%)$} \\
\hline & & C. c & C. b & \\
\hline 1. & Acaulospora capsiculata Blaszk. & - & 5.71 & 50 \\
\hline 2. & Acaulospora delicata Walker, Pfeiffer \& Bloss & - & 2.86 & 50 \\
\hline 3. & Acaulospora denticulata Sieverding \& Toro & 7.89 & - & 50 \\
\hline 4. & Acaulospora lacunosa Morton & - & 2.86 & 50 \\
\hline 5. & Acaulospora tuberculata Janos \& Trappe & 5.26 & 2.86 & 100 \\
\hline 6. & Glomus clarum Nicolson \& Schenck & - & 2.86 & 50 \\
\hline 7. & Glomus clavisporum (Trappe) Almeida \& Schenck & 7.89 & 5.71 & 100 \\
\hline 8. & Glomus eburneum Kenn., Stutz \& Morton & 2.63 & - & 50 \\
\hline 9. & Glomus etunicatum Becker \& Gerdemann & 7.89 & 25.71 & 100 \\
\hline 10. & Glomus geosporum (Nicol. \& Gerd.) Walker & 2.63 & 8.57 & 100 \\
\hline 11. & Glomus lamellosum Dalpe, Koske \& Tews & 2.63 & - & 50 \\
\hline 12. & Glomus luteum Kenn., Stutz \& Morton & 10.53 & 14.29 & 100 \\
\hline 13. & Glomus macrocarpum Tul. \& Tul. & 13.16 & 8.57 & 100 \\
\hline 14. & Glomus melanosporus Gerd. \& Trappe & 2.63 & - & 50 \\
\hline 15. & Glomus microcarpum Tul. \& Tul. & 5.26 & 5.71 & 100 \\
\hline 16. & Glomus spurcum Pfeiff., Walker \& Bloss & 2.63 & - & 50 \\
\hline 17. & Glomus tortuosum Schenck \& Smith & 7.89 & - & 50 \\
\hline 18. & Glomus trimurales Koske \& Halvorson & - & 2.86 & 50 \\
\hline 19. & Glomus verruculosum Blaszkowski \& Tadych & 15.79 & 11.43 & 100 \\
\hline 20. & Glomus versiforme (Karsten) Berch & 5.26 & - & 50 \\
\hline
\end{tabular}

Note: C.c $=$ Clerodendrum colebrookianum, C.b $=$ Clerodendrum bachananii, IF $=$ Isolation frequency and '-' = absence of species.

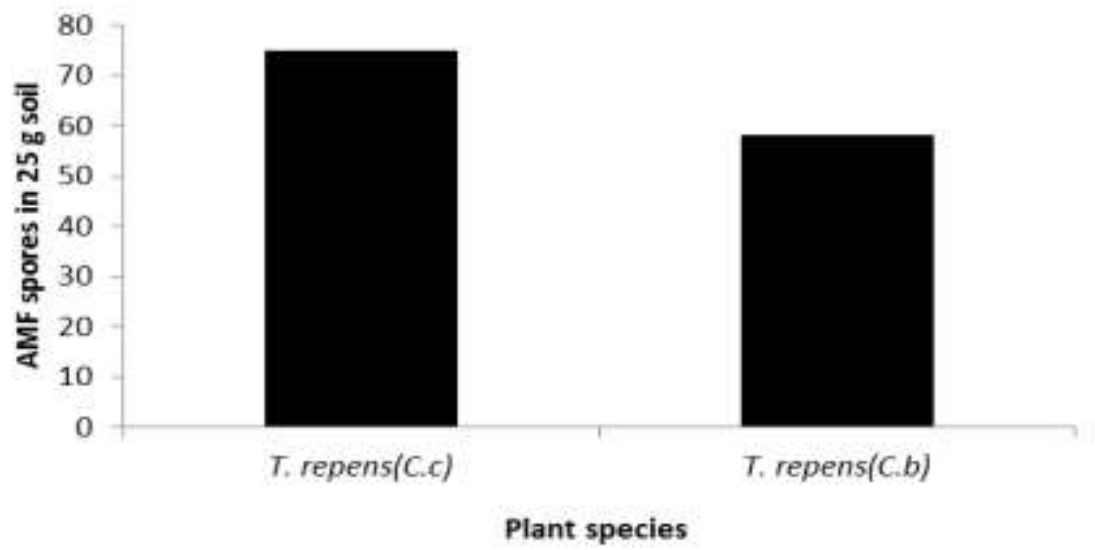

Fig. 3 - AMF spore density in the trap culture of Clerodendrum species.

Note: $C . c=C$. colebrookianum, $C . b=C$. bachananii 
Table 5 AMF species isolated from trap plants (Trifolium repens) with inoculum source from two Clerodendrum species.

\begin{tabular}{|c|c|c|c|c|}
\hline \multirow{2}{*}{ S1. No. } & \multirow{2}{*}{ AMF species } & \multicolumn{2}{|c|}{ Relative abundance (\%) } & \multirow{2}{*}{$\mathrm{IF}(\%)$} \\
\hline & & T.r (C.c) & T.r (C.b) & \\
\hline 1. & Acaulospora delicata Walker, Pfeiffer \& Bloss & - & 6.25 & 50 \\
\hline 2. & Acaulospora denticulata Sieverding \& Toro & 7.14 & - & 50 \\
\hline 3. & Glomus badium sp. nov. Oehl, Redecker \& Sieverd. & 7.14 & 6.25 & 100 \\
\hline 4. & Glomus brasilianum Spain \& Miranda & - & 6.25 & 50 \\
\hline 5. & Glomus clarum Nicolson \& Schenck & 14.29 & - & 50 \\
\hline 6. & Glomus eburneum Kenn., Stutz \& Morton & 7.14 & - & 50 \\
\hline 7. & Glomus etunicatum Becker \& Gerdemann & 14.29 & 18.75 & 100 \\
\hline 8. & Glomus fistulosum Skuo and Jakobsen & - & 6.25 & 50 \\
\hline 9. & Glomus geosporum (Nicol. \& Gerd.) Walker & 14.29 & 12.5 & 100 \\
\hline 10. & Glomus intraradices Schenck \& Smith & - & 18.75 & 50 \\
\hline 11. & Glomus luteum Kenn., Stutz \& Morton & - & 6.25 & 50 \\
\hline 12. & Glomus macrocarpum Tul. \& Tul. & 21.43 & - & 50 \\
\hline 13. & Glomus mosseae (Nicol. \& Gerd.) Gerdemann \& Trappe & - & 6.25 & 50 \\
\hline 14. & Glomus verruculosum Blaszkowski \& Tadych & 14.29 & 12.5 & 100 \\
\hline
\end{tabular}

Note: T.r $=$ Trifolium repens, C.c $=$ Clerodendrum colebrookianum, $\mathrm{C} . \mathrm{b}=$ Clerodendrum bachananii, $\mathrm{IF}=$ Isolation frequency and ' - ' $=$ absence of species.

\section{Discussion}

Low AMF colonization rates were observed in Clerodendrum colebrookianum and $C$. buchananii. AMF colonization in this study was lower than those reported in other plant species from this region (Das \& Kayang 2010; Songachan \& Kayang 2011). The variation in AMF colonization associated with different host plant species may be generated by a variety of potential mechanisms, including biological characteristics of rhizosphere under host species, mycorrhizal dependency, host plant-mediated alteration of the soil microenvironment $(\mathrm{Wu}$ et al (2009), AMF diversity and species composition (Gange et al. 1990), or seasonal and ontogenetic variations (Jakobsen et al. 2002) and nutrient demands of the host (Muthukumar \& Udaiyan 2002). All together, 20 AMF species (15 from C. colebrookianum and 13 from $C$. buchananii) belonging to Acaulospora and Glomus species were isolated and identified. Glomus were the most common species followed by Acaulospora, in both plants, which is consistent with the study of Li et al (2007) and Charoenpakdee et al (2010) in different ecosystems. In fact, Glomus is the most widely distributed AMF species and it is considered as cosmopolitan in many ecosystems (Sýkorová et al. 2007). Tchabi et al (2009) reported that G. etunicatum which is one of the dominant species in this study tend to be a dominant species in soil samples from the yam field sites.

Other AMF species such as those belonging to Gigasporaceae are capable of propagation only with viable spores or from an intact mycelium whereas Glomeraceae are capable of colonizing even with fragments of mycelium (Biermann \& Linderman 1983). Moreover, large spores AMF species require a longer period to develop than the small spore species (Hepper 1984) and as sampling was done just once, it is possible that in our study we could not detect 

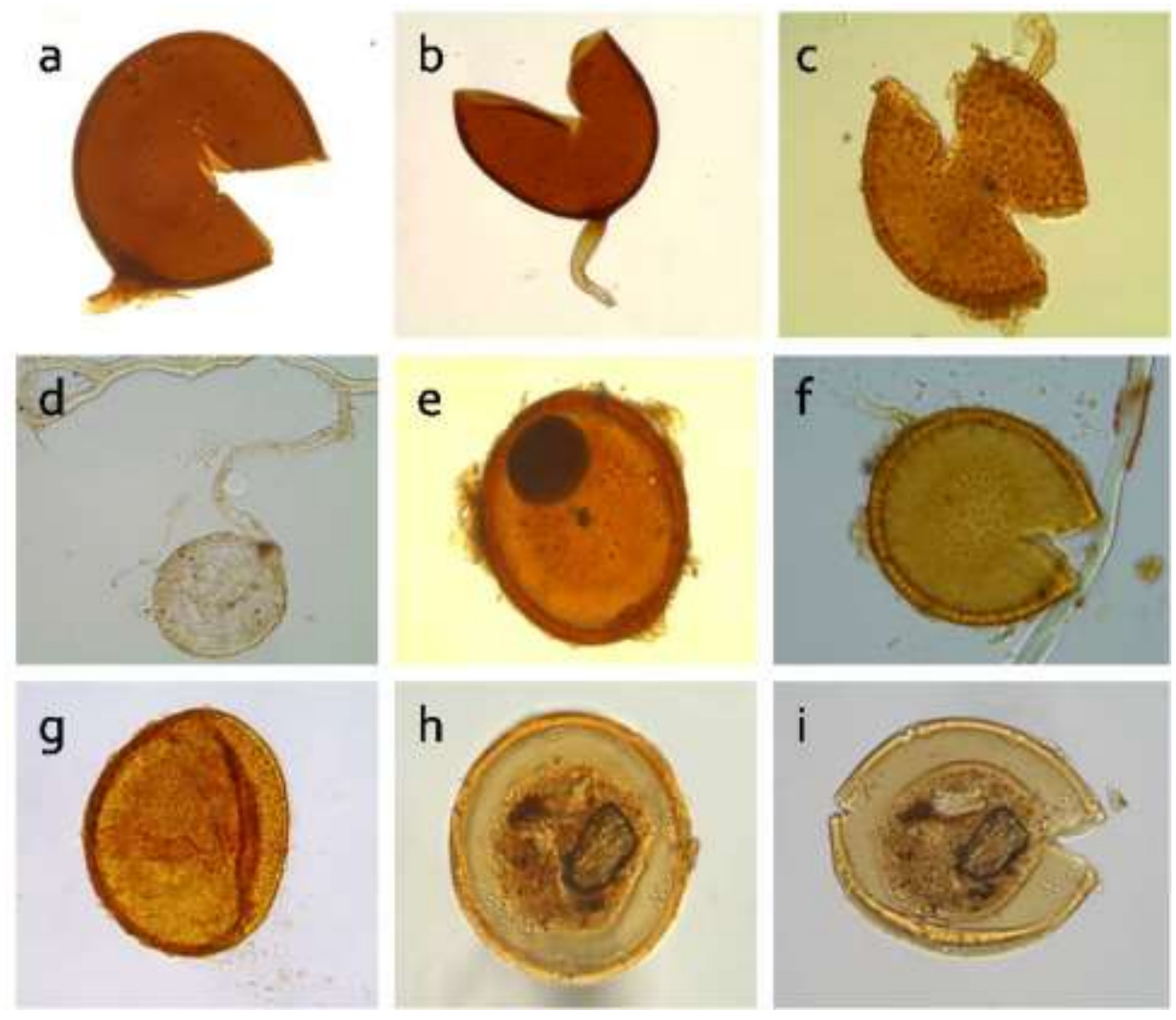

Fig. 4 - Some of the isolated AMF spores from Clerodendrum rhizosphere soils. a-f: Glomus species (G. etunicatum, G. geosporum, G. lamellosum, G. viscosum, G. macrocarpum and $G$. clarum; g-i: Acaulospora species (A. denticulate, h \& i A. delicata).

other genus of AMF. Individual AMF species compete for resources through a combination of strategies resulting in the maintenance of a diverse AMF community (Koske 1987) and thus, AMF species having high competitive interaction and adaptability likely dominates in the rhizosphere of the Clerodendrum species.

AMF colonization was higher in trap culture set up with inoculum source from $C$. buchananii (18.07 \%) as compared to that set up with C. colebrookianum (16.31\%). However, spore density was higher in $C$. colebrookianum derived inoculum source than those with $C$. buchananii derived inoculum source. 14 AMF species were recovered from trap cultures (8 species from C. colebrookianum and 10 species from C. buchananii). Additional AMF species i.e., two species in C. colebrookianum trap culture (Glomus badium and G. clarum) and five species in C. buchananii (G. badium, G. brasilianum, G. fistulosum, G. intraradices and G. mosseae) were obtained which otherwise were not recovered in the original field soils. Similarly, high proportions of additional species appearing exclusively in the trap cultures and not in the original field soil were reported by Oehl et al (2004). Occurrence of additional AMF species in the traps is a well documented phenomenon, justifying the use of trap cultures for more complete AMF surveys than direct isolation of spores from the field soils (Oehl et al. 2004). Therefore, this approach should be incorporated in the analysis of AMF species diversity as it revealed additional AMF species (Stutz \& Morton 1996) and produce healthy spores that can be use for inoculum conservation. 
AMF are ecologically important root symbionts of most terrestrial plants, and its benefits are increasingly acknowledged. The present study provides basic information on the status of AMF colonization and diversity in Clerodendrum species. Many plant species are in high demand for their medicinal properties and other various purposes. Therefore, recognition of mycorrhizal status, and application of mycorrhizal technology could be of particular value in different field.

\section{Acknowledgement}

The authors thank the Head, Department of Botany, North Eastern Hill University, Shillong, Meghalaya, India for providing laboratory facilities.

\section{References}

Adeneye AA, Adekele TI, Adeneye AK. 2008 - Hypoglycemic and hypolipidemic effects of the aqueous fresh leaves extract of Clerodendrum capitatum in Wistar rats. J Ethnopharmacol 116 (1), 7-10.

Allen SE, Grinshaw HM, Parkinson JA, Quaramby C. 1974 - Chemical analysis of ecological materials. Blackwell Scientific Publications, Oxford.

Anderson JM, Ingram JSI. 1993 - Tropical Soil Biology and Fertility. A handbook of methods. CAB International, Oxford.

Biermann B, Linderman RG. 1983 - Use of vesicular-arbuscular mycorrhizal roots, intraradical vesicles and extraradical vesicles as inoculum. New Phytologist 95, 97-105.

Chae S, JS Kim, KA Kang, Bu HD, Lee Y, Hyun JW, Kang SS. 2004- Antioxidant activity of jionoside D from Clerodendrum inerme. Biological and Pharmaceutical Bulletin 27, 1504-1508.Charoenpakdee S, Cherdchai P, Dell B, Lumyong S. 2010 - The mycorrhizal status of indigenous arbuscular mycorrhizal fungi of physic nut (Jatropha curcas) in Thailand. Mycosphere 1(2), 167-181.

Das P, Kayang H. 2010 - Arbuscular mycorrhizal fungi and dark septate endophyte colonization in bamboo from Northeast India. Front. Agric. China 4(3), 375-382.

Fuchs B, Haselwandter K. 2008 - Arbuscular mycorrhiza of endangered plant species: potential impacts on restoration strategies. In: Varma A. (ed) Mycorrhiza: state of the art, genetics and molecular biology, eco-function, biotechnology, eco-physiology, structure and systematics. Heidelberg: Springer.

Gange AC, Brown VK, Farmer LM. 1990 - A test of mycorrhizal benefit in an early successional plant community. New Phytologist 115, 85-91.

Hepper CM. 1984 - Isolation and culture of VA mycorrhizal (VAM) fungi. In: VA Mycorrhizae. (eds. CL Powell, DJ Bagyaraj) CRC Press, Florida, USA. pp 95-112.

Jadeja RN, Thounaojam MC, Ramani UV, Devkar RV, Ramachandran AV. 2011 - Anti-obesity potential of Clerodendron glandulosum.Coleb leaf aqueous extract. Journal of Ethnopharmacology 135 (2), 338-343.

Jadeja RN, Thounaojam MC, Singh TB, Devkar RV, Ramachandran AV. 2012 - Traditional uses, phytochemistry and pharmacology of Clerodendron glandulosum Coleb - a review. Asian Pacific Journal of Tropical Medicine 1-6.

Jakobsen I, Smith SE, Smith FA. 2002 - Function and diversity of arbuscular mycorrhizae in carbon and mineral nutrition. In: van der Heijden MGA, Sanders IR. (eds), Mycorrhizal ecology, p. 75-88, Springer, Berlin. 
Koske RE. 1987 - Distribution of VA mycorrhizal fungi along a latitudinal temperature gradient. Mycologia 79, 55-68.

Li LF, Zhang Y, Zhao ZW. 2007 - Arbuscular mycorrhizal colonization and spore density across different land-use types in a hot and arid ecosystem, Southwest China. Journal of Plant Nutrition and Soil Science 170, 419-425.

McGonigle TP, Miller MH, Evans DG, Fairchild GL, Swan JA. 1990 - A new method which gives an objective measure of colonization of roots by vesicular-arbuscular mycorrhizal fungi. New Phytologist 115, 495-501.

Muthukumar T, Udaiyan K. 2002 - Seasonality of vesicular arbuscular mycorrhizae in sedges in a semi-arid tropical grassland. Acta Oecologica 23, 337-347.

Nakata M. 1999. - Evaluation of the antioxidant activity of environmental plants: activity of the leaf extracts from seashore plants. Journal of Agriculture and Food Chemistry 47, 17491754.Oehl F, Sieverding E, Mäder P, Dubois D, Ineichen K, Boller T, Wiemken A. 2004 - Impact of long-term conventional and organic farming on the diversity of arbuscular mycorrhizal fungi. Oecologia 138, 574-583.

Philips JM, Hayman DS. 1970 - Improved procedures for clearing roots and staining parasitic and vesicular - arbuscular mycorrhizal fungi. Trans Br Mycol Soc. 55, 158-160.

Ryszka P, Błaszkowski J, Jurkiewicz A, Turnau K. 2010 - Arbuscular mycorrhiza of Arnica montana under field conditions-conventional and molecular studies. Mycorrhiza 20, 551-557.

Schussler A, Schwarzott D, Walker C (2001) A new fungal phylum, the Glomeromycota: phylogeny and evolution. Mycol Res 105:1413-1421.Smith SE, Read DJ. 2008 Mycorrhizal symbiosis, $3^{\text {rd }}$ edn. Academic, London.

Somasundram S, Sadique J. 1986 - Anti-hemolytic effect of flavonoidal glycosides of C. inerme: An in vitro study. Fitoterapia 57, 103-110.

Songachan LS, Kayang H. 2011 - Diversity of arbuscular mycorrhizal fungi in pine forest of Meghalaya, North East India. Mycosphere 2(4), 497-505.

Stutz JC, Morton JB. 1996 - Successive pot cultures reveal high species richness of arbuscular mycorrhizal fungi in arid ecosystems. Canadian Journal of Botany 74, 1883-1889.

Sýkorová Z, Ineichen K, Wiemken A, Redecker D. 2007 - The cultivation bias: different communities of arbuscular mycorrhizal fungi detected in roots from the field, from bait plants transplanted to the field, and from a greenhouse trap experiment. Mycorrhiza 18: $1-14$.

Tchabi A, Burger S, Coyne D, Hountondji F, Lawouin L, Wiemken A, Oehl, F. 2009 Promiscuous arbuscular mycorrhizal symbiosis of yam (Dioscorea spp.), a key staple crop in West Africa. Mycorrhiza 19, 375-392.

Uma E, Muthukumar T, Sathiyadash K, Muniappan V. 2010 - Mycorrhizal and dark septate fungal associations in gingers and spiral gingers. Botany 88, 500-511.

Wu Y, Liu T, He X. 2009 - Mycorrhizal and dark septate endophytic fungi under the canopies of desert plants in Mu Us Sandy Land of China. Frontiers of Agriculture in China 3(2), $164-170$. 